\title{
IMPLANTAÇÃO DA CAIXINHA DA SAUDADE NO CENTRO OBSTÉTRICO PÓS ÓBITO FETAL
}

Eixo temático: Avaliação e qualidade do cuidado

Ana Ligia Padovan Brunello; Andrea Mayumi Loureiro Hayashi; Cássia Aparecida Pereira Leal; Solange Felomeno Caramello Hypolito; Vanessa Cerávolo Gurgel Silva.

\begin{abstract}
INTRODUÇÃO
A gravidez acarreta em um conjunto de transformações físicas, psíquicas e sociais que envolvem o casal e o meio em que estão inseridos, sendo vista como um momento de vida e não de morte, portanto quando ocorre, resulta em marcas profundas e traumáticas nos pais e nas pessoas que vivenciam esse momento 1.

A realidade da parturição, torna necessidade impar, desenvolver uma prática humanizada, competente e capaz de proporcionar uma assistência de qualidade, envolvimento e compromisso ético, onde a parturiente possa receber dos profissionais competência e amor humano ${ }^{2}$.
\end{abstract}

\section{OBJETIVO}

Humanizar o cuidado às puérperas e familiares diante do óbito fetal, através da política de humanização com a Caixinha da Saudade, a fim de confortar aqueles envolvidos com a perda.

\section{METODOLOGIA}

Pesquisa observacional no período de Setembro a Dezembro 2018 no centro obstétrico do Hospital Municipal Vereador José Storopolli, em São Paulo.

\section{RESULTADOS}

Após o óbito fetal a mãe e a família são acolhidas pela equipe de enfermagem previamente treinados no manejo e na comunicação de más noticias, ofertando suporte e esclarecimentos necessários. O natimorto então é entregue a mãe para contato mais intimo e por tempo suficiente, nestes casos imagens podem ser registradas através de fotos. A mãe receberá da enfermeira uma caixinha denominada "Caixinha da Saudade" contendo uma pulseira com marcadores do parto (nome completo da mãe, registro hospitalar, data e hora do nascimento, sexo, peso e altura do bebê) e um clamp umbilical estéril. Diante da ação foi observado melhora da aceitação do processo da perda pela mãe e familiares, pois houve relatos de uma experiência agradável em relação ao óbito de seu filho querido.

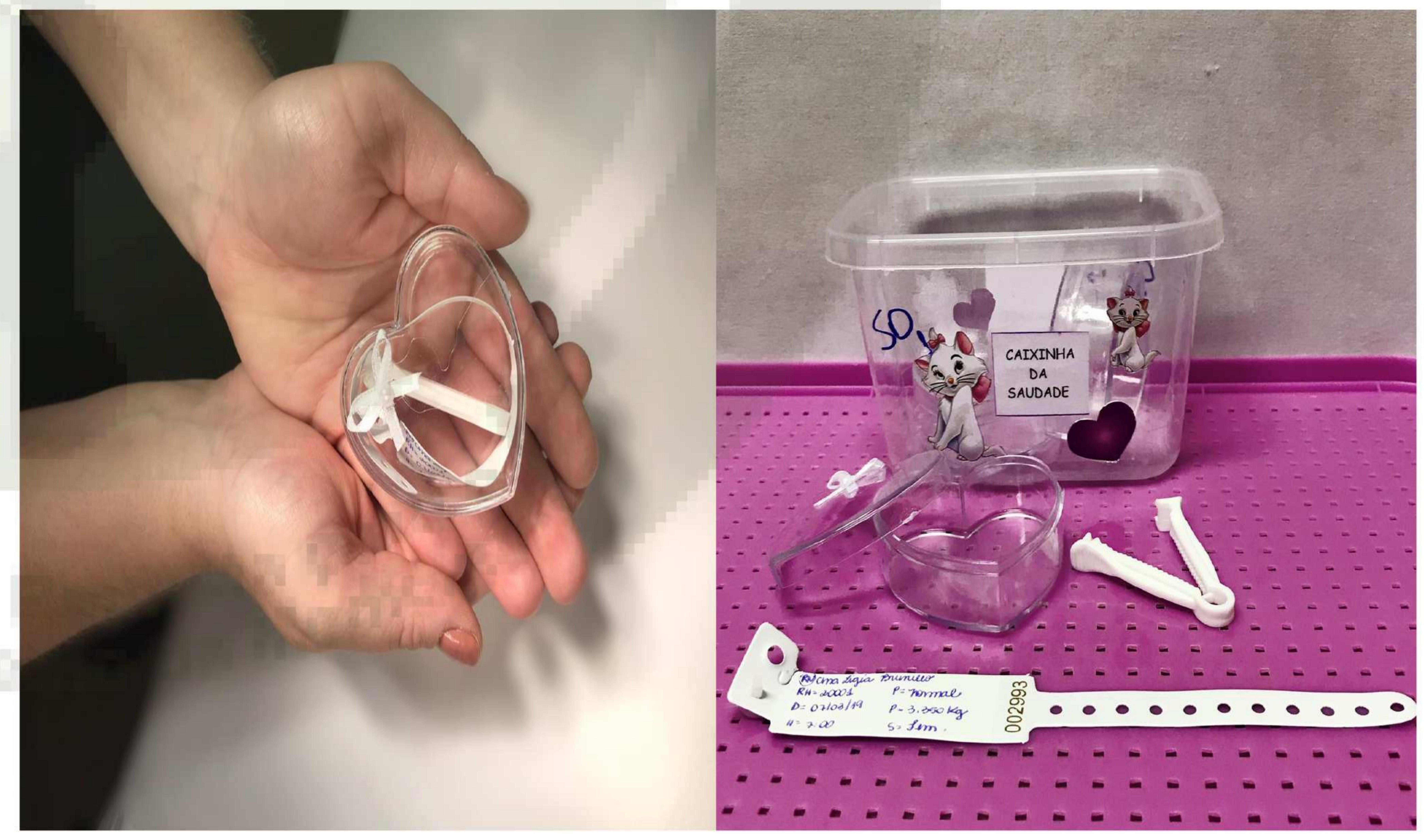

Figura 1 - Caixinha da Saudade.

\section{CONCLUSÃO}

A implantação da "Caixinha da Saudade" no Centro Obstétrico, foi uma estratégia que visa melhorar a forma com que a enfermagem presta a assistência às mulheres acometidas com o óbito fetal após o parto. A mãe sofre a mudança repentina de um momento de alegria pelo nascimento do filho, mas logo recebe a notícia do óbito, causando-Ihe dor e sofrimento. Esse ato visa amenizar o sofrimento da mãe e familiares, diante do fato de receber uma lembrança que trará conforto e recordações eternas.

\section{REFERÊNCIA}

1 - SANTOS, CS. Percepção de enfermeiras sobre a assistência prestada a mulher diante do óbito fetal. Ceará, abr/jun.2012. v16(2), p.277-284. 2 - COSTA, R. ROCHA, L. Cuidados à mulher que vivência o óbito fetal: Um desafio para equipe de enfermagem. Universidade Federal de Santa Catarina. Florianópolis, abr.2016. p.23-137 